\title{
Major Advances Associated with Hormone and Growth Factor Regulation of Mammary Growth and Lactation in Dairy Cows
}

\author{
R. M. Akers \\ Department of Dairy Science, Virginia Polytechnic Institute and State University, Blacksburg 24061
}

\begin{abstract}
In recent years, the number of researchers interested in mammary development and mammary function in dairy animals has declined. More importantly this cadre of workers has come to rely more than ever on scientists focused on and funded by breast cancer interests to provide fundamental mechanistic and basic cellular insights. Philosophically and practically this is a risky path to better understand, manipulate, and control a national resource as important as the dairy cow. The efficiency, resourcefulness, and dedication of dairy scientists have mirrored the actions of many dairy producers but there are limits. Many of the applications of research, use of bovine somatotropin, management of transition cows, estrus synchronization techniques, and so on, are based on decades-old scientific principles. Specific to dairy, do rodents or breast cancer cell lines adequately represent the dairy cow? Will these results inspire the next series of lactation-related dairy improvements? These are key unanswered questions. Study of the classic mammogenic and lactogenic hormones has served dairy scientists well. But there is an exciting, and bewildering universe of growth factors, transcription factors, receptors, intracellular signaling intermediates, and extracellular molecules that must ultimately interact to determine the size of the mature udder and the functional capacity of mammary gland in the lactating cow. We can only hope that enough scientific, fiscal, and resource scraps fall from the biomedical research banquet table to allow dairy-focused mammary gland research to continue.
\end{abstract}

Key words: growth hormone, mammary, signaling, lactation

\section{INTRODUCTION}

The endocrine system, perhaps more than any other physiological system, plays a central role in all aspects

Received January 8, 2005.

Accepted February 17, 2005.

E-mail:rma@vt.edu of mammary development (mammogenesis), onset of lactation (lactogenesis), and maintenance of milk secretion (galactopoiesis). Lactogenesis is frequently described as a 2-stage process. Stage I consists of limited structural and functional differentiation of the secretory epithelium during the last third of pregnancy. Stage II involves completion of cellular differentiation during the immediate periparturient period coinciding with onset of copious milk synthesis and secretion. These are the essential developmental phases that characterize physiological requirements that ultimately allow lactation to occur. Thus, logic predicts that alterations in activity of hormones or growth factors that modify the mammary gland during any of these phases could impact milk production. My goals for this review are: 1) to provide some highlights that emphasize new findings and directions specific to endocrine and growth factor modulation of the udder; 2) to offer some background and perspective; and 3) to ponder what the future might bring.

Although this is not a history lesson, some perspective on recent cellular, molecular, and biotechnology seemingly "gee-whiz" results is important. Experiments in the 1920s showed that injection of pituitary extracts induced milk secretion in virgin rabbits. Subsequently, the purified protein responsible for this milk secretion response was determined to be prolactin (Prl). Even now, the widely touted and used galactopoietic effect of growth hormone (GH) or bovine somatotropin to increase milk production in lactating dairy cows had its foundation in studies by Asimov and Krouze in the 1930s. British researchers, focused on efforts to improve and maintain milk supplies during World War II, initiated many endocrine studies on mammary development and function in dairy animals. The effects of estrogen and progesterone on mammogenesis were extensively evaluated in attempts to induce lactation in nonpregnant animals. In the 1970s, there was a flurry of activity on hormonal induction of lactation in cattle based on a variety of short-term injection schemes using estrogen and progesterone. Positive correlations between milk yields following induction and concentrations of Prl were noted. Greater milk yields for cows induced into lactation during the 
spring and summer (compared with winter) was also attributed to higher serum concentrations of Prl.

As its name suggests, Prl has been the most intensely studied hormone related to lactation and mammary growth. Despite long-term knowledge that the presence of the pituitary is essential for normal mammary development, whether Prl or GH is predominating in mammogenesis is not clear. The answer to this question is likely species-dependent. Regardless, application of molecular techniques to mammary gland biology has solidified the idea that Prl and glucocorticoid $(\mathbf{G})$ are primary stimulators of mammary cell differentiation. For example, both $\mathrm{Prl}$ and G response elements are found within the promoter regions of the genes for several mammary-specific milk proteins. Similarly, induction of both mRNA and specific milk proteins in response to addition of $\mathrm{Prl}$ or $\mathrm{G}$ in isolated mammary epithelial cells confirm the importance of these hormones in lactogenesis and provide details for mechanisms of action of these hormones in control of milk protein gene expression.

My point is simple; despite the advent of new technologies-genomics, proteomics, microarrays, real time PCR, serial analysis of gene expression, etc.- the fundamentals remain the same. Can we better understand mechanisms that control secretory cell proliferation in the udder and secondly define elements that control the secretory capacity of mature, functionally differentiated secretory cells? Compared with the past, the focus for understanding these mechanisms now has a much stronger cellular and molecular twist but the practical goals are similar. How do we maximize milk production without compromising animal health, reproduction, or longevity?

\section{GALACTOPOIESIS AND BOVINE SOMATOTROPIN}

Would it be possible to consider hormones or growth factors that have influenced the dairy industry in the past $25 \mathrm{yr}$ without putting $\mathrm{GH}$ at the top of the list? Clearly, administration of bST to lactating dairy cows increases the yield and efficiency of milk production. After an injection of bST, milk secretion increases within a day and is maximized within a week. Elevated milk yield is maintained as long as treatment is continued but quickly returns to control levels when bST is discontinued. The dose-dependent milk yield response curve follows a hyperbolic pattern. A near maximal response is obtained at approximately $40 \mathrm{mg}$ of bST/ d. Typically, bST increases milk production by 4 to 6 $\mathrm{kg} / \mathrm{d}$, approximately a 10 to $15 \%$ increase in yield. The magnitude of response to a particular dose of bST depends upon biological variation, stage of lactation, and management parameters. The bST formulation cur- rently approved for use in the United States is a prolonged-release n-methionyl-bST (Posilac, Monsanto Co., St. Louis, MO) that was approved by the FDA in November 1993. It is administered at a dose of 500 $\mathrm{mg} / \mathrm{cow}$ every 2 wk. Package instructions are that treatment should be initiated after peak lactation at $>60 \mathrm{~d}$ postcalving, when cows are at or near positive energy balance. The first year after approval, average milk yield increased $3 \mathrm{~kg}$ and this level of increase for bST-adopting herds has been maintained.

Given the voluminous literature and now very widespread commercial use of bST in dairy cows in the United States and other countries, testing and evaluation of this technology has likely been the most intensely scrutinized new animal technology in history. Public debate about bST use was also extensive. Special interest groups and very public individuals predicted dire consequences from adoption of bST for use in dairy cows. Among concerns with little scientific basis, it was thought that bST approval would cause a massive reduction in milk consumption, milk price would decline, and farmers would go bankrupt. Others predicted dire animal consequences. Media coverage was extensive and intense around the time of FDA approval with more than 800 reports in the first quarter of the year. At the current time, the regulatory agencies of more than 50 countries have reviewed safety concerns and approved bST for use. It is estimated that more than 3 million cows currently receive bST supplementation. In the United States, this includes animals in herds of all sizes, located in every region of the country. Scientific and anecdotal information support the view that bST is a safe, effective, and profitable management tool for the dairy farmer. Although US food laws do not mandate labeling of milk from bST-treated cows (because the composition of the milk from the bST cows is equivalent to that of controls), a relatively small niche market has developed for milk obtained from herds not using bST. However, because there is no chemical test to distinguish the milk from bST- and non-bST-treated cows, validation of milk from non-bST-treated cows simply depends on the fact that these producers sign a certification declaring that bST is not used on their farms. This is analogous to niche markets for organic farmed products. A recent estimate is that milk from these farms constitute less that $1 \%$ of fluid milk sales in the United States. This suggests that the vast majority of consumers are interested in wholesome food products obtained at competitive prices. In fact, during the first year after approval, milk fluid consumption in the United States increased about $1 \%$.

Reasons for some of the rancorous debate on the approval of bST for use in dairy cows were varied but 
logic suggests several elements were important. This was the first proposition for widespread treatment of animals with a recombinant DNA-derived product that influenced not animal health, but animal production. Secondly, the wholesomeness of milk and milk products seem to occupy a special position when compared with many other food materials. Thirdly, the now-refuted dire predictions of consequences on animal health coincided with a growing affluence and associated "greening" of attitudes among many segments of the population. Finally, popular concerns that adoption of the technology might hasten the disappearance of family farms and change the sociology of rural farm areas was seemingly carried along on a wave of nostalgia at the time. Certainly it was an interesting process to observe.

Scientific work surrounding bST continues. For example, a September 2004 search of the CAB Direct library database using somatotropin as a search word with the search restricted to journal articles after 1990 yielded a total of 5,698 papers. A Boolean logic search using the combination [somatotropin AND bovine], [somatotropin AND mammary], or [somatotropin AND mammary AND bovine] produced 1,352, 352, and 94 journal articles, respectively. Using just the Journal of Dairy Science Web site, a search using somatotropin returned 224 papers between 1990 and September 2004; a more restricted search using [mammary AND bST] produced 33 papers. Many of these bST papers address practical aspects; that is, are milk production, mammary growth, and other physiological processes affected by treatment with bST. However, studies in laboratory animals or in vitro model systems are beginning to unravel details of signal transduction pathways and hints about complex interactions between mammary relevant hormones and growth factors. Results from these very basic studies are progressively being gleaned to provide molecular tools to explore mechanisms that more specifically apply to mammary development and lactation in farm animals. An example is the somewhat unsettled view of the presence of specific (functional) bST receptors in the bovine mammary gland. Traditional binding assays typically showed very little evidence for receptors in mammary microsomes but studies using sensitive PCR techniques or immunocytochemistry indicate that growth hormone receptors are present.

\section{SIGNAL TRANSDUCTION}

The explosion of endocrine and growth factor specific data is most dramatically related to signal transduction pathways for target cells. For our discussion, we want to know how these various groups of hormonal and growth factor agents exert their effects on the mammary secretory cells. For many years we have known that protein or peptide-like molecules first bind to cell surface receptors. The question is how this action elicits specific target cell responses. Changes in cell function depend on synthesis and/or activation of cellular proteins. Consequently, transcriptional regulators or transcription factors that control gene activation must regulate mammary growth, morphogenesis, and ultimately, milk synthesis. Does this mean that all hormone or growth factor stimulation of the mammary gland boils down to a reflection of the population of transcription factors/inhibitors that are activated in the mammary alveolar cells at a given moment? The answer at some level is probably yes. Let's consider intracellular signaling and transcription factor activation tied to 2 of the classic lactogenic hormones.

Signal transduction specific to $\mathrm{Prl}$ and GH has only recently been elucidated. However, additional complexity derives from expression of multiple forms of the hormone receptors. These receptors are members of the structurally related cytokine receptor superfamily, which includes several interleukins, erythropoietin, and leptin, among others. Both Prl receptor (PrlR) and GH receptor (GHR) are single-chain proteins with a single transmembrane domain such that the protein spans the entire plasma membrane. Each hormone has 2 sites capable of binding to its receptor protein. Initially, the hormone binds to its receptor to create an inactive complex. This hormone-receptor complex diffuses within the membrane of the mammary cell to link with another receptor protein. This causes receptor homodimerization and formation of an active complex. Studies with mutant forms of Prl or GH have confirmed the importance of homodimerization in hormone action. Versions of Prl or GH with impaired binding sites are unable to form homodimer pairs with their respective receptor proteins and are devoid of biological activity. Stimulation of target cells with Prl or GH causes tyrosine phosphorylation of many cellular proteins. But the cytoplasmic domains of the receptors have no inherent enzymatic activity. This means that hormone binding and dimer formation have to activate other cellular kinases.

A breakthrough to understanding this signaling cascade came with the discovery that Janus tyrosine kinases (JAK) were activated after hormone binding and homodimerization. These kinases belong to a family with 4 members: JAK1, JAK2, JAK3, and nonreceptor tyrosine protein kinase. For Prl-R and GHR, JAK2 is especially important. For Prl-R, JAK2 is constitutively associated with the receptor, but with GHR the enzyme associates with the receptor only after hormone binding and dimer formation. 
The signaling pathway depends on JAK2 induced phosphorylation of a transcription factor(s) called a signal transducer and activator of transcription (STAT). One of these, STAT5, is specifically implicated in Prl stimulation of the casein gene in mammary tissue. There are 2 isoforms of STAT5 (STAT5a and STAT5b). When phosphorylated, these proteins form homo- and heterodimers that translocate to the nucleus of the mammary cell. Understanding some of the physiological consequences of Prl signaling has been gained through studies on mice in which the genes encoding Prl-R, STAT5a, and STAT5b have been genetically inactivated or modified. The STAT5a isoform is the critical isoform in rodent mammary gland and STAT5a-deficient mice fail to lactate because of impaired lobulo-alveolar development. Female mice with only one intact Prl-R allele (i.e., heterozygous for Prl$\mathrm{R}$ null allele) fail to lactate after their first pregnancy because mammary development is markedly impaired. This suggests that mammary development during gestation depends on a threshold amount of Prl-R expression that cannot be provided by one functional allele. How these findings translate to the bovine is unknown but it is likely that $\mathrm{Prl}$ is important in mammogenesis in addition to its well-appreciated impact on lactogenesis in dairy cows. For example, changes in expression of Prl-R in animals exposed to long or short photoperiods during the dry period and linked effects on the IGF axis are thought to be a mechanism for effects of a short photoperiod to enhance mammary cell proliferation and thus, increased milk yields.

In both rat and bovine mammary explant cultures, addition of GH, Prl, or insulin-like growth factor I (IGF-I) stimulates STAT5 DNA binding activity. Conversely, when mammary explants were incubated for $1 \mathrm{~h}$ in the absence of lactogenic hormones, STAT5 activity was not detectable, but inclusion of either Prl or GH stimulated the additive appearance of STAT5DNA binding complexes. These responses are not directly linked to new protein synthesis but rather activation. Activity of STAT5 is readily detected in mammary tissue of lactating cows but not in the mammary tissue of nonlactating cow, and activity is increased with milking frequency and was moderately correlated $(\mathrm{r}=0.51)$ with milk protein percentage. Unexpectedly, long-term treatment of lactating cows with $\mathrm{GH}$ or GHreleasing factor raised milk production but depressed STAT5 activity in the mammary gland. In contrast, these treatments had no effect on abundance of STAT5 protein in the mammary gland. These results support the idea that STAT5 activation and protein synthesis are affected by physiological status and that hormones known to impact differentiated mammary function
(Prl, GH, and IGF-I) may all impact the mammary epithelium by a common signaling pathway.

In the bovine, there are 2 isoforms of the Prl-R. The so-called long-form Prl-R transmits Prl-mediated signals across the cell membrane. The function of the short form of the receptor is less understood. However, evidence suggests that short Prl-R is antagonistic to the long Prl-R, perhaps because it can limit availability of local Prl for binding to the long Prl-R. From rodent studies, both forms of the receptor dimerize when Prl binding occurs and several mediators are activated, including JAK2, and mitogen-activated protein kinase. However, only stimulation via the long form of the receptor induces $\beta$-casein expression. Thus, there are subtle differences between the receptor types that must explain differences in function.

It is intuitive that changes in circulating concentrations of Prl or receptor numbers in target tissues affect sensitivity to Prl, but there is increasing evidence for negative aspects of the Prl signaling axis. A related group of intracellular regulators, the suppressors of cytokine signaling (SOCS), modulate activities of cytokines including Prl. The best understood members of the group include SOCS-1, -2, -3, and cytokine-inducible SH2-containing protein. Ironically, transcription of SOCS genes is stimulated by Prl. Is it reasonable that, in some circumstances, Prl induces the appearance of factors that block Prl action? This inhibition of Prl signaling occurs via inhibition of JAK kinase activity. Specifically, SOCS family members block STAT binding sites or increase proteolysis of transcription factors. What controls this balance?

The synergistic effects of $\operatorname{Prl}$ and G on induction of milk protein synthesis near the time of parturition are well known. There is a molecular answer for this effect. Positive enhancement of transactivation of STAT5 occurs via the receptor. Both the Prl and G receptor pathways in mammary cells require activation of latent transcription factors-STAT5 for Prl and G receptor $(\mathbf{G R})$ for the G. When the GR is bound, a conformational change occurs that frees receptor-bound heatshock proteins. The activated GR translocates from the cytoplasm into the nucleus of the cell where it binds to $\mathrm{G}$ response elements in the DNA. In the presence of both Prl and activated GR, a complex that preferentially binds to the STAT5 response elements is created. This enhances the induction of milk protein genes compared with Prl alone.

\section{GROWTH FACTOR SOUP}

For a time, it seemed that understanding the classic mammogenic and lactogenic hormones and their signaling cascades would explain the essentials of mam- 
mary growth and function. Figure 1 provides an overview of the lactogenic hormone axis and IGF axis signaling pathway as well as selected growth factors that affect mammary function. However, as with these hormones, molecular biology has opened what seems to be a Pandora's box of agents, factors, and regulators, many of which are certain to affect mammary development or function. Furthermore, other "growth factors" have an impact on milk production indirectly via their effects on appetite, metabolism, or other physiological processes. It is difficult to overstate the significance of technical advancements in cell and molecular biology and biotechnology that have allowed a major expansion in our understanding of structural relationships between mammary cell messengers. Based on detailed structural analysis at the DNA, RNA, and protein levels, many messengers not previously identified as being related have come to be grouped into families of molecules. In some cases, messengers are grouped based on structure of the protein, or grouped based on similarity of the receptors to which they bind. This is a time of astonishingly rapid advancements and accumulation of enormously detailed information. Unfortunately, it is also confusing as more details emerge to force reclassification or new understanding of these messengers. My goal in this section is not to provide a comprehensive review but rather to illustrate properties of some mammary active agents.

\section{THE IGF FAMILY}

To appreciate IGF-I, a brief history is required. The primary function of $\mathrm{GH}$ is promotion of linear growth. But many of its growth-promoting effects are indirectly mediated by stimulation of the liver to produce IGF-I. This is called the somatomedin hypothesis. Initially, IGF-I and IGF-II were called somatomedin A and $\mathrm{B}$, to account for their relationship with $\mathrm{GH}$ action. However, once structures of the molecules were determined it became clear that these molecules were similar to insulin, hence the new names. Regardless, it is now certain that many actions originally attributed to GH are mediated by IGF-I, but it should not be forgotten that many tissues also express GH receptors. The liver is the primary source for IGF-I in circulation but IGF-I is also produced locally in many tissues. In at least some cases, locally produced IGF-I is as important as circulating IGF-I. The value of nonliver sources of IGF-I became clear from knockout mouse studies. In these experiments, genetic engineering techniques were used to block or knock out normal liver IGF-I synthesis. Despite this insult, these animals exhibited essentially normal growth and development. In many situations, local production of IGF-I can replace or supplement circulating IGF-I coming from the liver. Other complications include the discovery of a family of IGF-I binding proteins (IGFBP). These molecules also appear in circulation and are produced locally. Depending on conditions, these proteins can either inhibit or enhance biological effects associated with IGF-I. Some of these relationships are illustrated in Figure 2. The solid arrows illustrate the pathways associated with the "classic" somatomedin hypothesis, and the dashed arrows illustrate more recent findings related to local production of IGF-I and IGFBP.

Figure 3 demonstrates synthesis of IGF-I by stromal cells in the bovine mammary gland. In this instance, stromal tissue and isolated mammary epithelial cells were tested for the presence of mRNA for IGF-I. The IGF-I mRNA detected in samples of mammary parenchymal tissue is actually synthesized by stromal tissue cells that surround the developing mammary ducts. It is increasingly clear that the IGF family of growth factors, receptors, and binding proteins is important in many aspects of mammary development and function. Insulin-like growth factors I and II are widely expressed endocrine-, autocrine-, or paracrine-acting peptides that regulate cell growth, cell differentiation, maintenance of cell function, and prevention of apoptosis in multiple cell types. The IGF-I receptor (IGF-IR) is the primary signaling receptor for the IGFI peptide. Other related actions that affect cell signaling include cell-cell communication and cell-extracellular matrix (ECM) interactions. These ultimately change function because of changes in tissue development.

In the cow, normal circulating concentrations of 1 to $5 \mathrm{ng} / \mathrm{mL}$ of insulin have little ability to signal via IGF-IR. This is relevant because many of the classic culture experiments with explanted mammary tissue used additions of 500 to $1,000 \mathrm{ng} / \mathrm{mL}$ of insulin to support viability of the tissues. Consequently, effects originally attributed to insulin were likely caused by insulin binding to IGF-IR. Insulin-like growth factor I can also bind to the insulin receptor but with much less affinity. The situation is confounded by the existence of hybrid receptors between IGF-IR and the native insulin receptor that have higher affinity for IGF than for insulin. There are as many as 5 distinct types of insulin IGF-I hybrid receptors. This can markedly change the diversity of signaling induced by binding of insulin or IGF.

Signaling pathways and biological effects are best characterized for IGF-IR and insulin receptor-B but experiments in cell culture model systems support the idea that combinations of native and hybrid receptors allow both overlapping and unique physiological ef- 


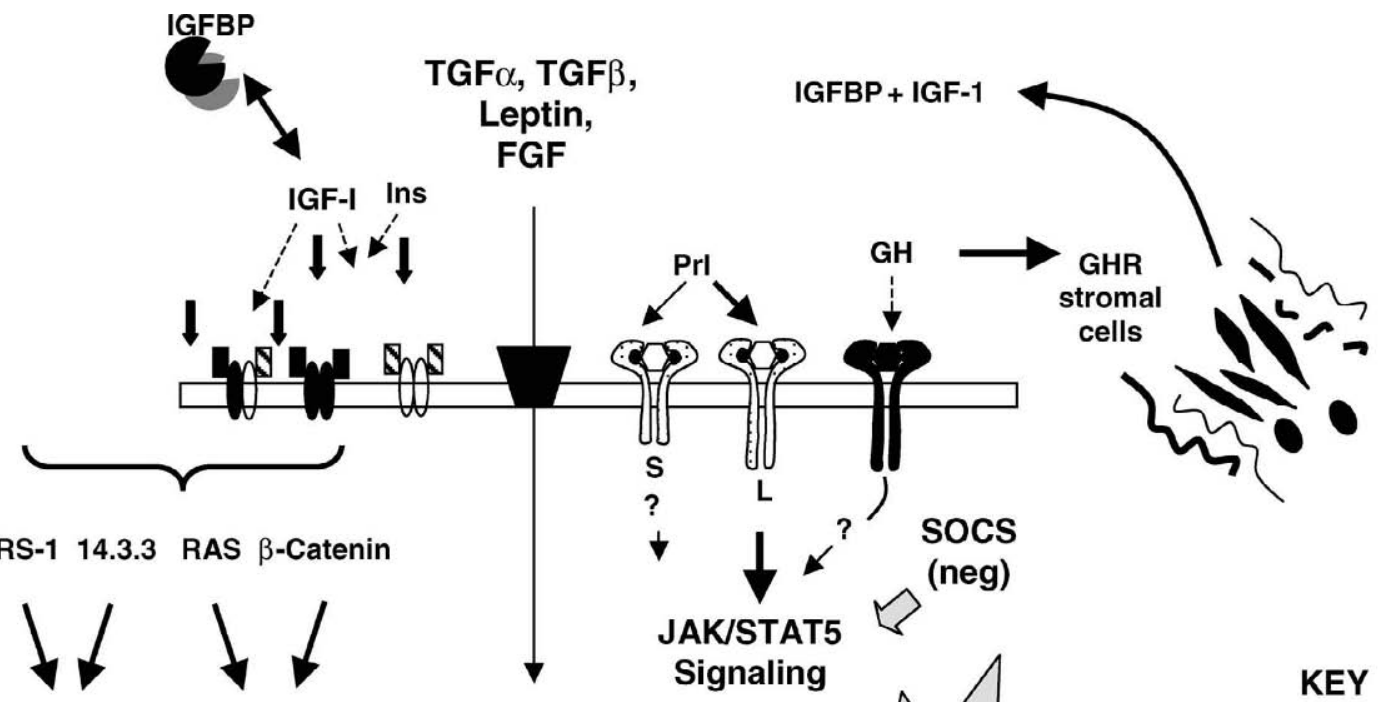

Figure 1. Overview of action of insulin-like growth factor I (IGF-I), prolactin (Prl), growth hormone (GH), and selected growth factors in a bovine mammary epithelial cell. The plasma membrane is depicted by the horizontal bar. Receptors for IGF-I and insulin and associated hybrid receptors are shown on the left. Primary pathways are denoted by heavy solid arrows, less well established or alternative pathways are denoted by lighter arrows, dashed arrows, or question marks. Signaling via IGF-I binding to IGF receptor follows 1 of 4 primary branches. Activation of insulin receptor substrate I (IRS-I), induced by ligand binding, and autophosphorylation of the receptor creates docking sites for insulin receptor substrate proteins. This initiates activation of phosphatidylinositol 3 'kinase (PI3K) and serine threonine kinase (Akt) that ultimately promotes cells survival. This is because the proapoptotic protein BAD, which causes cell death, is phosphorylated in the presence of Akt and is therefore inhibited. Activation of the 14.3.3. family of proteins as a consequence of effects on the serine threonine kinase, raf1, also promotes cell survival by inactivation of BAD. Activation of Ras proteins named for the Ras gene, first identified in viruses that cause sarcoma in rats) and various connected intermediates stimulates cyclin D1 and promotes cell proliferation. The final pathway depends of the phosphorylation of $\beta$-catenin, which stimulates the expression of cyclin D1 and promotes cell proliferation. Availability and biological actions of IGF-I depend on local stromal tissue production of IGF-I and IGF binding proteins (IGFBP) and sources derived from circulation. Prolactin receptor (Prl-R) is expressed in both a short (S) and long (L) form. However, response to the long form is better understood. Prolactin binding to the L isoform induces receptor homodimerization and activation of Janus protein kinase 2 (JAK2), which phosphorylates STAT5, one of a family of transcription factors that increases expression of milk protein genes in and activation of Janus protein kinase 2 (JAK2), which phosphorylates STAT5, one of a family of transcription factors that increases expression of milk protein genes in
the structurally differentiated mammary alveolar cell. Responses are modified by actions of other hormones (estrogen, glucocorticoids, and progesterone), interactions with extracellular matrix (ECM) proteins, and degree of differentiation of the alveolar cells. Ironically, a negative controller of STAT5 activation, the suppressors of cytokine signaling (SOCS), is also induced by prolactin. Although presence of GH receptors in bovine mammary gland has been confirmed by immunological and molecular tools, it is unclear that GH effects in the udder are direct; that is, via STAT activation. Evidence for GH effects on mammary stromal cells to stromal production of IGF-I and IGFBP seems more certain. Actions of other growth factors in bovine mammary gland [transforming growth factor (TGF) $\alpha$ and $\beta$, fibroblast growth factor (FGF), leptin are not as well described but presence of receptors are confirmed and responses of bovine mammary cells in culture established. It may be that these agents are especially important at only particular stages of development. 


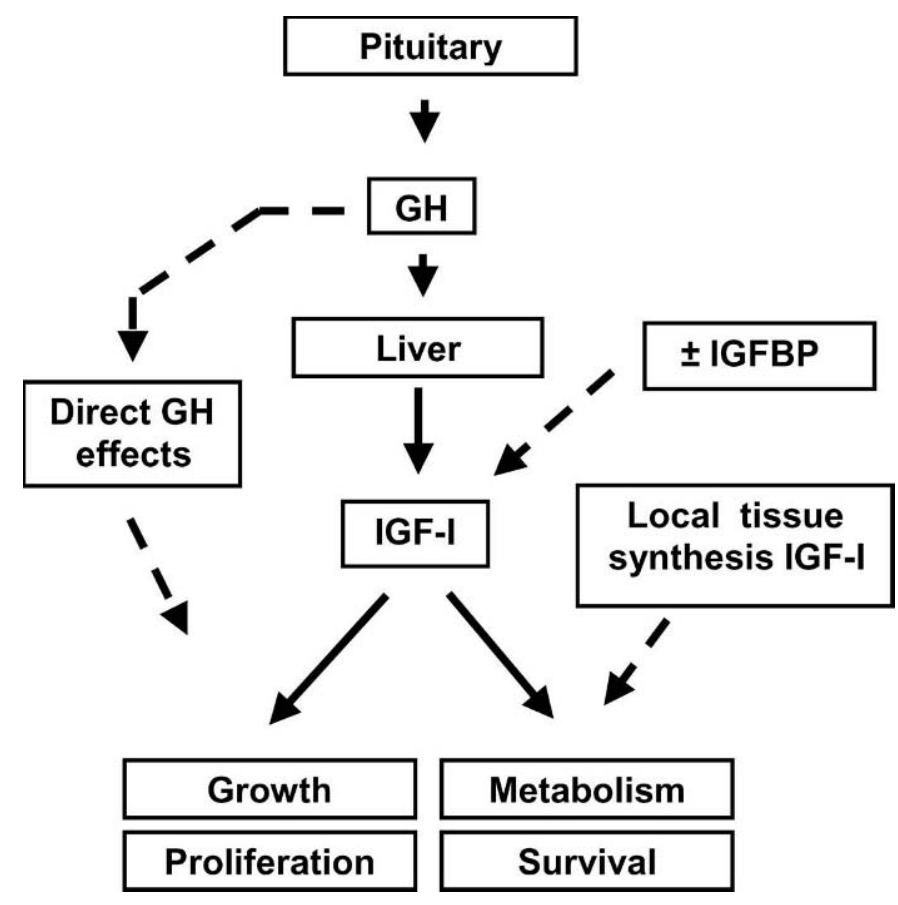

Figure 2. The modified somatomedin hypothesis. Relationships between secretion of pituitary growth hormone (GH) and liver IGFI are illustrated by the solid arrows. Dashed arrows indicate direct effects of GH, significance of local tissue production of IGF-I, and the role of IGF-I binding proteins (IGFBP) in control of biological actions of IGF-I.

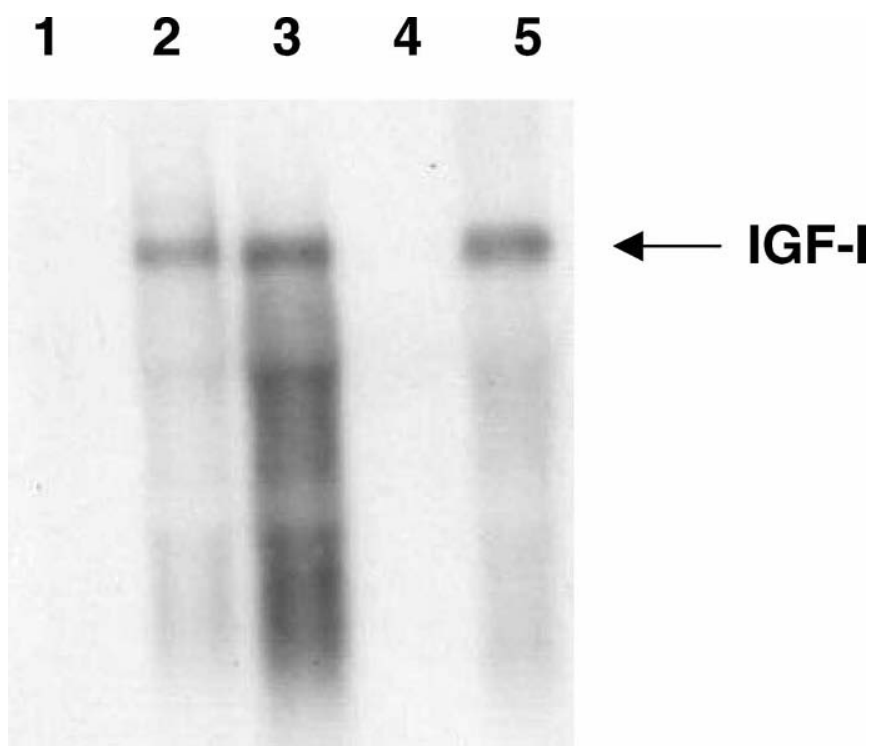

Figure 3. Bovine mammary tissue expression of IGF-I. Shown is a Northern analysis of IGF-I mRNA expression (arrow) of mammary epithelial cells or stromal tissue prepared from heifer mammary tissue. Lanes 1 and 4 represent RNA from epithelial cells, lanes 2 and 3 represent RNA from stromal tissue, and lane 5 represents RNA from liver (control). Note that there is a signal for IGF-I in samples of mammary stroma and liver RNA but not in mammary epithelial cell RNA. Data are adapted from Berry et al., 2003. fects. Activation of the IGF-IR can generate intracellular effects through at least 4 distinct but overlapping pathways. In general, stimulation of IGF-IR is associated with cell cycle progression and cell survival.

Studies with rodents in which various elements of the IGF-I axis were deleted confirm that IGF-I and IGFI-R are essential for normal mammary development. These studies and related rodent experiments show that in normal peripubertal mammary development, $\mathrm{GH}$ acts to bind to $\mathrm{GH}$ receptors in the stromal tissue. This is associated with local production of IGFI, which in turn promotes the development of the mammary ducts. For example, overexpression of recombinant IGF-I in the mammary glands of transgenic mice promotes premature mammary development. Impaired mammary development in ovariectomized heifers is linked to reduced local production of IGF-I and increased IGFBP-3.

In addition to IGF-I and IGF-II, there are 6 IGFBP and 9 related proteins that affect the actions of IGFI and II. The IGFBP are well characterized and bind IGF-I with $~ 10$-fold higher affinity than the IGFBP related proteins. The IGFBP have several functions including prolonging the half-life of IGF-I, transporting IGF-I from the circulation, and localizing IGFI to potential target cells. In particular, locally produced IGFBP provide a mechanism to target or localize IGF and thereby alter biological responses to either systemic or locally produced IGF. Some members of the IGFBP family are most frequently associated with inhibition of IGF-I action by preventing IGF from binding to its receptor; other IGFBP potentiate IGF responses by facilitating ligand-receptor interaction. It seems likely that the binding proteins, especially IGFBP-3, have biological effects not directly tied to their capacity to modify IGF-I action; IGFBP-3 is abundant in mammary secretions that accumulate during mammary development.

Along with locally produced IGF-I made by stromal cells (see Figure 3), mammary cells also synthesize IGFBP-1, 2, 3, and 5. Insulin-like growth factor binding protein 3 is usually touted as an inhibitor of responses to IGF-I. For example, Figure 4 shows increased proliferation of mammary tissue following treatment with estrogen, $\mathrm{GH}$, or the combination and the associated mirror image decrease in tissue concentrations of IGFBP-3. It seems that at least some of the proliferation induced with these classic mammogenic hormones is mediated by a local reduction in mammary tissue IGFBP-3. There is also increased tissue IGF-I, again suggesting the importance of IGF-I axis molecules in regulation of bovine mammary development. 

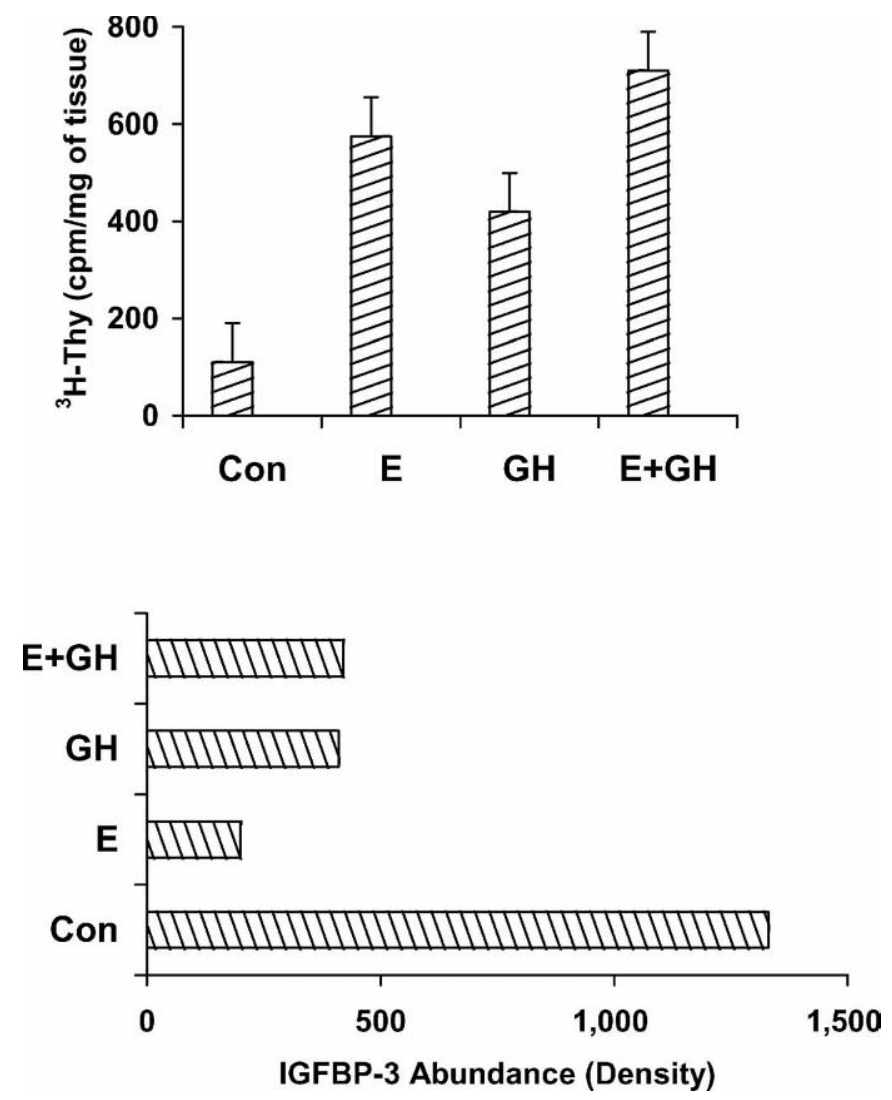

Figure 4. Thymidine incorporation in mammary tissue and IGFI binding protein 3 (IGFBP-3). The upper panel shows increased DNA synthesis in mammary tissue of heifers treated with placebo (Con), estradiol (E), growth hormone (GH), or estradiol and growth hormone $(\mathrm{E}+\mathrm{GH})$. The lower panel illustrates the relative abundance of IGFBP3 in mammary tissue from these same animals. Note that increased proliferation in treated animals corresponds with decreased tissue IGFBP-3 (adapted from Berry et al., 2001).

\section{EPIDERMAL GROWTH FACTOR FAMILY}

Epidermal growth factor (EGF) was discovered by accident in the 1960s when unexpected biological activity occurred following injections of extracts of murine salivary glands into test animals. These effects were associated with precocious eyelid opening and tooth eruption in neonates. Subsequent studies showed that preparations containing EGF stimulated proliferation of isolated epidermal cells and epidermal tissue explants, hence the name EGF. Study of a human epidermal cancer cell line (A-431) was fundamental in subsequent studies because these mutated cells greatly overexpressed receptors for EGF. This property allowed for the isolation and eventual structural characterization of the receptor. The availability of relatively large quantities of receptor led to the discovery that addition of EGF to isolated membranes stimulated phosphorylation of both endogenous membrane proteins as well as many exogenously added proteins. It was subsequently shown that the receptor protein was a $170-\mathrm{kDa}$ transmembrane glycoprotein whose external domain formed the binding site for EGF and whose cytoplasmic domain possessed tyrosine kinase activity. Epidermal growth factor bound to the external portion of the receptor activates the cytoplasmic or catalytic domain of the receptor to produce autophosphorylation and subsequently phosphorylation of cytoplasmic substrates essential for EGF action. These observations were important because they were among the first to directly link ligand binding, receptor activation, and phosphorylation as a general mechanism of action for many growth factors.

This family of proteins contains at least 10 members including EGF, heparin-binding EGF, transforming growth factor $\alpha$ (TGF- $\alpha$ ), amphiregulin, neuroregulins (4 subtypes), and several heregulins. Each of these structurally similar proteins acts by binding to one of several related membrane receptors called type I receptor tyrosine kinases or the ErbB family of receptors. The usual EGF receptor is called ErbB-1 but at least 4 variants are known. Certain receptors in the family, ErbB-2 (also called Her2 or Neu), contributes to the aggressive phenotype of some human breast carcinomas.

Epidermal growth factor is important in normal mammary gland development in mice and probably other species as well. There is compelling evidence to suggest that estrogen induces local production of EGF agonists (EGF itself, TGF- $\alpha$, and amphiregulin), and that these agents are important in alveolar development. Receptors for EGF are present in regions of rapidly growing mammary ducts, including the surrounding stromal cells. The importance of these proteins in mammogenesis in farm animals is less well established but specific EGF receptors and EGF mRNA are found in ruminant mammary tissue. There is a single class of high-affinity binding sites in mammary tissue of sheep and cows during gestation and into lactation. However, the number of receptors is greater during midpregnancy than in late pregnancy or during lactation. Expression of TGF- $\alpha$ occurs in the bovine but amphiregulin is found in ovine mammary tissue. Addition of either TGF- $\alpha$ or EGF stimulates DNA synthesis in explants from midpregnant heifers, or epithelial cells from heifers or pregnant cows and sheep. Figure 5 shows the effect of EGF on DNA synthesis in mammary explants prepared from tissue taken from midpregnant heifers. For freshly prepared explants, concentrations of EGF of less than $10 \mathrm{nM}$ stimulated DNA synthesis after $2 \mathrm{~d}$ in culture. Intramammary infusion of EGF stimulated DNA synthesis in udders of pregnant heifers but it is not clear if this 


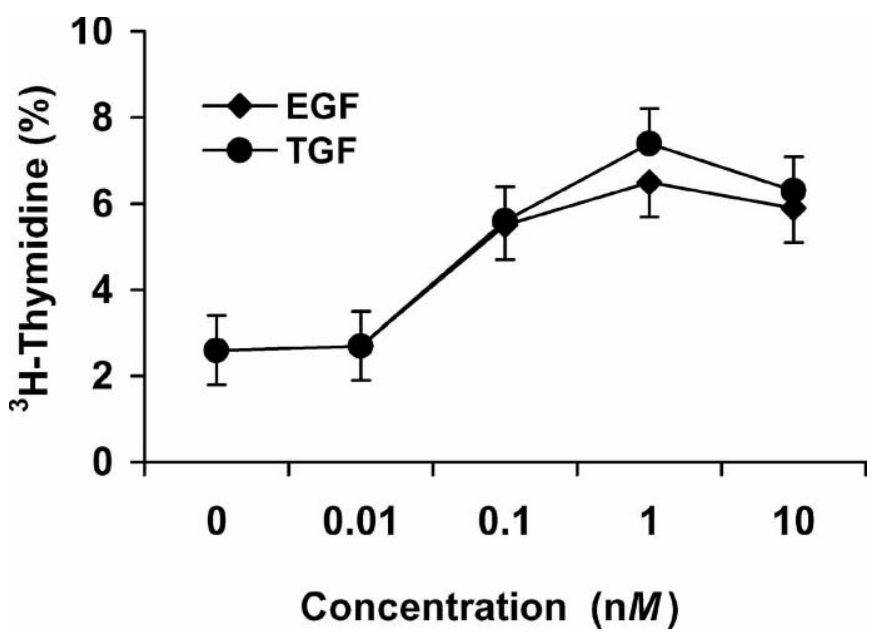

Figure 5. Epidermal growth factor (EGF) and bovine mammary cell growth. Autoradiographic analysis of EGF or transforming growth factor- $\beta$ (TGF- $\beta$ )-stimulated DNA synthesis in bovine mammary tissue explants from midpregnant Holstein heifers. Tissues were incubated for $2 \mathrm{~d}$ in the presence of the growth factors and DNA synthesis was measured during the last $6 \mathrm{~h}$ of cultured by measurement of tritiated thymidine incorporation. Data are adapted from Sheffield, 1998; ㄷ1998, The Endocrine Society.

represents augmentation of a normal response to naturally occurring EGF in the bovine mammary gland or a pharmacological effect.

Presence of EGF receptors, ligands, and demonstrated response of ruminant mammary cells to EGF support a role for these growth factors in mammogenesis but much more information is needed to determine exact roles. In short, it is not known if the EGF family of proteins and receptors are largely permissive or if they have an essential direct impact in ruminant mammary development.

\section{FIBROBLAST GROWTH FACTOR FAMILY}

Fibroblast growth factors (FGF) constitute a family of 20 small peptide growth factors that share a highly homologous core of 140 amino acids and strong affinity for heparin and heparin-like glycosaminoglycans of the ECM. Fibroblast growth factor signaling and interactions with the ECM have attracted the attention of numerous cancer researchers because of the potential role of the FGF in promoting the progression of some tumors from a hormone-dependent to a hormone-independent pattern of growth. Both FGF-1 (also known as acidic FGF or aFGF) and FGF-2 (also known as basic FGF or bFGF) were first identified from extracts of bovine pituitary glands based on the capacity of the proteins to stimulate DNA synthesis in cultured fibroblasts. By convention, they continued to be designated as FGF despite the fact that not all of the pro- teins actually stimulate proliferation of fibroblasts. Several members of the FGF family have emerged as stroma-derived mitogens. They act in a paracrine manner to locally influence epithelial cell proliferation and glandular morphogenesis by controlling appearance of side branching and patterning of mammary ductal growth.

At least 3 of the known FGF variants [FGF-1, FGF-2, and FGF-7 (also known as keratinocyte growth factor)] are involved in ruminant mammary development. These FGF and their receptors are expressed throughout the lactation cycle but highest levels of expression were in glands of virgin heifers and in primiparous heifers during involution. Interactions between epithelium and the surrounding stroma influence paracrine FGF-2 expression. Specifically, expression is greater in the stroma adjacent to the developing parenchymal tissue compared with more distant mammary stromal tissue.

\section{TRANSFORMING GROWTH FACTOR- $\beta$ FAMILY}

The transforming growth factor $\beta$ (TGF- $\beta$ ) group of proteins is made up of at least 5 multifunctional proteins that have functions ranging from modification of the ECM to induction of differentiation of target cells and stimulation of proliferation in multiple cell types and tissues. At least 28 genes encode for various elements of this family of proteins and companion receptors. Three of the variants (TGF- $\beta 1$, TGF- $\beta 2$, and TGF $\beta$-3) stimulate connective tissue formation and are chemotactic for fibroblasts. They can indirectly promote proliferation of mesenchymal cells but can inhibit growth of epithelial cells in vivo and in vitro.

Transforming growth factor $\beta 1$ is the best described of these proteins related to mammary function. Blood platelets provide the most concentrated source of TGF$\beta 1$, but nearly every cell type in the body is thought to produce TGF- $\beta 1$. Biologically active TGF- $\beta 1$ is a 25 $\mathrm{kDa}$ disulfide-linked homodimer. When secreted, it is bound to a large $75-\mathrm{kDa}$ glycoprotein called the latency-associated peptide. Activation of the latent form by proteases, alkalinization, or chaotropic agents is necessary for TGF- $\beta 1$ to bind to its receptor so that control of this reaction is an important regulator of TGF- $\beta 1$ action. Unregulated epithelial cell proliferation is obviously an undesirable trait of tumor formation, so it should not be surprising that actively growing cells must be controlled to prevent hyperplasia. Most of the mammary-associated effects of TGF- $\beta$ are inhibitory. For example, TGF- $\beta 1$ inhibits IGF-I or serum-stimulated growth of primary bovine mammary epithelial cells in culture. 
Effects of TGF- $\beta$ are mediated by binding to specific cell surface receptors (designated type I, II, or III receptors) present on most cell types. The type I and type II receptors are directly involved in signal transduction, whereas the type III receptor is thought to enhance binding of TGF- $\beta$ to one of the other receptor subtypes. In heifers, the ductal epithelial cells of the mammary gland show extensive presence of type I and type II receptors by immunocytochemical localization.

Transforming growth factor $\beta 1$ reversibly inhibits the growth of mammary ducts. Application of exogenous TGF- $\beta$ inhibits epithelial cell proliferation within hours, and it induces localized ECM synthesis over several days. In the mouse, overexpression of TGF- $\beta$ transgenes at puberty markedly reduces the rate of duct development as well as the degree of ductular tree expansion. Expression during pregnancy impairs lobulo-alveolar development and therefore lactation. A model is that TGF- $\beta 1$ acts to stabilize ductular structures in a concentration-dependent manner to prevent duct entanglement by altering ECM formation during the period of rapid duct elongation. Such a model would then depend on the relaxation of these restraints for formation of side branches and alveolar budding.

The specific role of TGF- $\beta 1$ in ruminant mammary development is unknown but TGF- $\beta 1$ is present in serum, and receptors for TGF- $\beta 1$ in bovine mammary membranes are increased during the peripubertal period corresponding with rapid mammary development. Transforming growth factor $\beta 1$ is also expressed in the mammary tissue of virgin heifers. In vitro, TGF- $\beta 1$ produces a biphasic effect on proliferation of bovine mammary epithelial cell organoids from prepubertal heifers. Specifically, concentrations up to $500 \mathrm{pg} / \mathrm{mL}$ stimulate proliferation but concentrations greater than $1 \mathrm{ng} / \mathrm{mL}$ are inhibitory. Related studies show that TGF- $\beta 1$ inhibits proliferation normally observed with addition of IGF-I, IGF-II, des (1-3)-IGF-I, EGF, or amphiregulin. Transforming growth factor $\beta 1$ also affects morphology of bovine mammary organoids in culture. The possibility that IGFBP-3 (or fragments) might have IGF-I receptor independent actions in mammary cells, via binding to the type V TGF- $\beta$ receptor, coupled with TGF- $\beta$ induction of IGFBP-3, makes for an intriguing overlap between the growth-stimulating actions of the IGF-I axis and the inhibitory effects of the TGF$\beta$ family of molecules. Members of the TGF- $\beta$ family are important in early embryonic development and maintenance of homeostasis in adult tissue (including changes in mammary development) by affecting cell growth, differentiation of epithelial cells, and apoptosis.
The signaling cascade for TGF- $\beta$ is similar to other growth factors, and involves binding of the ligand to cell surface receptors. These receptors are transmembrane serine/threonine kinases. A current model is that binding induces the creation of a receptor complex composed of type I and type II receptors. Receptor II then acts to phosphorylate receptor I, the active element. Specifically, cytoplasmic Smad (combined name derived from Mad gene from Drosophila and Sma gene for Caenorhabditis elegans) proteins are substrates for the activated receptor. In TGF- $\beta$ signaling, I-Smads can block signaling by recruiting socalled Smurf ubiquitin ligases to capture various Smad proteins and target them for degradation. In summary, Smads can be thought of as transcriptional comodulators whose activity is controlled by various receptors of the TGF- $\beta$ superfamily of receptors via induction of nuclear accumulation of Smads.

\section{LEPTIN}

The concept of a circulating fat-derived regulator of feeding behavior was boosted by the discovery of genetic mutations in mice, the obese (ob) and diabetes (db) phenotypes. This led to the idea that the ob gene locus was essential for production of a circulating satiety factor and that the db locus encoded for a molecule capable of responding to this circulating agent. The product of the ob gene was subsequently named leptin, because of effects of the protein to reduce feed intake and body weight. Leptin is a $16-\mathrm{kDa}$ protein primarily produced in adipose cells. In nonruminants, it circulates both in a free form and bound to other proteins. Energy stores influence expression of the leptin gene as shown by increased adipose tissue leptin mRNA and serum concentrations in obese mammals. There is also a positive correlation between body fat stores and leptin concentrations in blood. Although adipose tissue is the major source of leptin, relatively lower levels of expression are found in many other tissues. It may be that local tissue production of leptin is also important. Indeed, leptin inhibited IGF-I or seruminduced proliferation of bovine mammary epithelial cells. Mammary epithelial cells express the long form of the leptin receptor. Increased local secretion of leptin in the developing udder may explain in part inhibitory effects of high-energy diets on mammary development in heifers. Synthesis of leptin by bovine mammary epithelial cells is stimulated by insulin or IGFI. This provides further support for the idea that leptin may act as an autocrine or paracrine signaling agent in the udder.

Cloning studies of the leptin receptor $(\mathbf{O b}-\mathbf{R})$ indicate the presence of at least 6 leptin receptor isoforms. 
Each of the isoforms has identical extracellular ligandbinding domains but variable cytoplasmic tails. Because expression of receptor isoforms is not uniform among target tissues, this adds an additional layer of complexity to understanding the physiological effects of leptin stimulation. For example, binding of leptin to the Ob- $\mathrm{R}_{\mathrm{L}}$ receptor or to one of the short forms of the receptor $\left(\mathrm{Ob}-\mathrm{R}_{\mathrm{a}}\right)$, with a 34-AA cytoplasmic tail, activates the tyrosine kinase Jak2, insulin receptor substrate I, and the mitogen-activated protein kinase pathway. However, only by binding to the $\mathrm{Ob}-\mathrm{R}_{\mathrm{L}}$ receptor can leptin also activate the STAT3 signaling pathway. It is known that stimulation of STAT3 is essential for many of the usual actions of leptin because the obesity defect in mutant $\mathrm{db} / \mathrm{db}$ mice is caused by failure of these mice to express the Ob- $R_{L}$ form of the leptin receptor. In normal animals, the Ob- $\mathrm{R}_{\mathrm{L}}$ receptor is expressed at high levels in regions of the hypothalamus involved in regulation of feed intake. This may mean that other forms of the leptin receptor are involved in physiological responses not directly related to nervous system control of feed intake. Unfortunately, studies in domestic animals and especially dairy animals are very limited. Sheep mammary gland expresses both the $\mathrm{Ob}-\mathrm{R}_{\mathrm{L}}$ and $\mathrm{Ob}-\mathrm{R}_{\mathrm{S}}$ leptin receptors with the greatest expression in epithelial cells. Interestingly, leptin is also increased in the serum of animals fed high-energy diets, which may be related to decreased mammary development that can occur in these animals. Moreover, leptin appears in milk and is present in cultured bovine mammary epithelial cells. Bovine mammary cells express mRNA for leptin and expression is increased by additions of insulin and IGF-I, both of which are known mediators of mammary function. This suggests that leptin may be an autocrine or paracrine signaling molecule in the mammary gland.

\section{CONCLUSIONS}

Despite the rich history that identified the classic mammogenic and lactogenic hormones, their receptors, and now some of the pieces of their signaling cascades, comprehensive understanding of mammary development and function, particularly in economically important dairy animals, is in its infancy. With the realization that there is a myriad of growth factors that target both mammary epithelial cells and stromal cells within the udder, complex networks of extracellular signals must interact to ultimately finalize the size of the mature mammary gland, and the capacity of the alveolar secretory cells to synthesize and secrete milk. An especially intriguing concept is that local modifiers of hormone action or locally produced growth factors may allow the mammary gland to control some of its destiny. As for the intracellular universe of receptors, signaling molecules, and transcription factors, it is a scientifically challenging but exciting time to be a mammary gland biologist or dairy scientist.

\section{REFERENCES}

Ahima, R. S., and J. S. Flier. 2000. Leptin. Annu. Rev. Physiol. 62:413-437.

Akers, R. M. 1985. Lactogenic hormones: Binding sites, mammary growth, secretory cell differentiation and milk biosynthesis in ruminants. J. Dairy Sci. 68:413-437.

Akers, R. M. 2002. Lactation and the Mammary Gland. Iowa State Press, Ames.

Akers, R. M., T. B. McFadden, S. Purup, M. Vestergaard, K. Sejrsen, and A. V. Capuco. 2000. Local IGF-I axis in peripubertal ruminant mammary development. J. Mammary Gland Biol. Neoplasia $5: 43-51$.

Asimov, G. J., and N. K. Krouze. 1937. The lactogenic preparations from the anterior pituitary and the increase of milk yield in cows. J. Dairy Sci. 20:289-306.

Bauman, D. E. 1999. Bovine somatotropin and lactation: From basic science to commercial application. Domest. Anim. Endocrinol. $17: 101-116$

Baumrucker, C. R., and N. E. Erondu. 2000. Insulin like growth factor (IGF) system in the bovine mammary gland and milk. J. Mammary Gland Biol. Neoplasia 5:53-65.

Blum, J. W., and C. R. Baumrucker. 2002. Colostrum and milk insulin-like growth factors and related substances: Mammary gland and neonatal (intestinal and systemic) targets. Domest. Anim. Endocrinol. 23:101-110.

Berlanga, J. J., J. P. Garcua-Ruiz, M. Perrot-Applanat, P. A. Kelly, and M. Edery. 1997. The short form of the prolactin (Prl) receptor silences Prl induction of the beta-casein gene promoter. Mol. Cell. Endocrinol. 11:1449-1457.

Berry, S. D., T. B. McFadden, R. E. Pearson, and R. M. Akers. 2001. A local increase in the mammary IGF-I:IGFBP-3 ratio mediates the mammogenic effects of estrogen and growth hormone. Domest. Anim. Endocrinol. 21:39-53.

Berry, S. D. K., R. D. Howard, P. M. Jobst, H. Jiang, and R. M. Akers. 2003. Interactions between the ovary and the local IGFI axis modulate mammary development in prepubertal heifers. J. Endocrinol. 177:295-304.

Bignon, C., N. Binart, C. Ormandy, L. A. Schuler, P. A. Kelly, and J. Djiane. 1997. Long and short forms of the ovine prolactin receptor: cDNA cloning and genomic analysis reveal that the two forms arise by different alternative splicing mechanisms in ruminants and in rodents. J. Mol. Endocrinol. 19:109-120.

Clemmons, D. R. 1998. Role of insulin-like growth factor binding proteins in controlling IGF actions. Mol. Cell. Endocrinol. 140:19-24.

Collier, R. J., J. C. Byatt, S. C. Denham, P. J. Eppard, A. C. Fabellar, R. L. Hintz, M. F. McGrath, C. L. McLaughlin, J. K. Shearer, J. J. Veenhuizen, and J. L. Vicini. 2001. Effects of sustained release bovine somatotropin (Sometribove) on animal health in commercial dairy herds. J. Dairy Sci. 84:1098-1108.

Cowie, A. T., I. A. Forsyth, and I. C. Hart. 1980. Hormonal Control of Lactation. Springer-Verlag Berlin, Heidelberg, Germany.

Dahl, G. E., B. A. Buchanan, and H. A. Tucker. 2000. Photoperiodic effects on dairy cattle: A review. J. Dairy Sci. 83:885-893.

Daniel, C. W., S. Robinson, and G. B. Silberstein. 1996. The role of TGF- $\beta$ in patterning growth of the mammary ductal tree. J. Mammary Gland Biol. Neoplasia 1:331-341.

Duan, C. 2002. Specifying the cellular response to IGF-I signals: Roles of IGF-I binding proteins. J. Endocrinol. 175:44-54.

Ellis, S., S. Purup, K. Sejrsen, and R. M. Akers. 2000. Growth and morphogenesis of epithelial cell organoids from peripheral and medial mammary parenchyma of prepubertal heifers. J. Dairy Sci. 83:952-961. 
Flint, D. J., E. Tonner, and G. J. Allan. 2000. Insulin-like growth factor binding proteins: IGF-dependent and independent effects in the mammary gland. J. Mammary Gland Biol. Neoplasia 5:65-73.

Goffin, V., and P. Kelly. 1997. The prolactin/growth hormone receptor family: Structure/function relationships. J. Mammary Gland Biol. Neoplasia 2:7-18.

Groner, B. 2002. Transcription factor regulation in mammary epithelial cells. Domest. Anim. Endocrinol. 23:25-32.

Hadsell, D. L., S. G. Bonnette, and A. V. Lee. 2002. Genetic manipulation of the IGF-I axis to regulate mammary gland development and function. J. Dairy Sci. 85:365-377.

Harris, R. C., E. Chung, and R. J. Coffey. 2003. EGF receptor ligands. Exp. Cell Res. 284:2-13.

Henninghausen, L., G. W. Robinson, K. Wagner, and X. Liu. 1997. Developing a mammary gland is a Stat affair. J. Mammary Gland Biol. Neoplasia 2:365-371.

Houseknecht, K. L., C. A. Baile, R. L. Matteri, and M. E. Spurlock. 1998. The biology of leptin: A review. J. Anim. Sci. 76:1405-1420.

Hovey, R. C., H. W. Davey, B. K. Vonderhaar, D. D. S. Mackenzie, and T. B. McFadden. 2001. Paracrine action of keratinocyte growth factor (KGF) during ruminant mammogenesis. Mol. Cell. Endocrinol. 181:47-56.

Hovey, R. C., T. B. McFadden, and R. M. Akers. 1999. Regulation of mammary gland growth and morphogenesis by the mammary fat pad: A species comparison. J. Mammary Gland Biol. Neoplasia 4:53-68.

Hovey, R. C., J. F. Trott, and B. K. Vonderhaar. 2002. Establishing a framework for the functional mammary gland: From endocrinology to morphology. J. Mammary Gland Biol. Neoplasia $7: 17-38$

Hynes, N. E., N. Cella, and M. Wartmann. 1997. Prolactin mediated intracellular signaling in mammary epithelial cells. J. Mammary Gland Biol. Neoplasia 2:19-27.

Ingvartsen, K. L., and J. B. Andersen. 2000. Integration of metabolism and intake regulation: A review focusing on periparturient animals. J. Dairy Sci. 83:1573-1597.

Kennedy, G. C. 1953. The role of depot fat in the hypothalamic control of feed intake in the rat. Proc. R. Soc. Lond., B, Biol. Sci. 139:578-592.

Kleinberg, D. L., M. Feldman, and W. Ruan. 2000. IGF-I an essential factor in terminal end bud formation and ductal morphogenesis. J. Mammary Gland Biol. Neoplasia 5:7-19.

Koff, M. D., and K. Plaut. 1995. Detection of transforming growth factor- $\alpha$ like messenger RNA in the bovine mammary gland. J. Dairy Sci. 78:1903-1908.

Lamote, I., E. Meyer, A. M. Massart-Leen, and C. Burvenich. 2004. Sex steroids and growth factors in the regulation of mammary gland proliferation, differentiation, and involution. Steroids 69:145-159.

Larsen, L., and C. Ropke. 2002. Suppressors of cytokine signaling: SOCS. APMIS 110:833-844

Laud, K., I. Gourdou, L. Belair, D. H. Keisler, and J. Djiane. 1999. Detection and regulation of leptin receptor mRNA in ovine mammary epithelial cells during pregnancy and lactation. FEBS Lett. 463:194-198.

Le Roith, D., C. Bondy, S. Yakar, J. Lui, and A. Butler. 2001. The somatomedin hypothesis 2001. Endocr. Rev. 22:53-74.

Li, A. G., M. I. Koster, and X. Wang. 2003. Roles of TFG- $\beta$ signaling in epidermal/appendage development. Cytokine Growth Factor Rev. 14:99-111.

Lindeman, G. J., S. Wittlin, H. Lada, M. J. Naylor, M. Santamaria, J. G. Zhang, R. Starr, D. J. Hilton, W. S. Alexander, C. J. Ormandy, and J. Visvader. 2001. SOCS1 deficiency results in accelerated mammary gland development and rescues lactation in prolactin receptor-deficient mice. Genes Dev. 15:1631-1636.

Liu, X., G. W. Robinson, K. U. Wagner, L. Garrett, A. WynshawBoris, and L. Hennighausen. 1997. Stat5a is mandatory for adult mammary gland development and lactogenesis. Genes Dev. $11: 179-186$
Moustakas, A., K. Pardali, A. Gaal, and C. H. Heldin. 2002. Mechanisms of TGF-beta signaling in regulation of cell growth and differentiation. Immunol. Lett. 82:85-91.

Musters, S., K. Coughlan, T. McFadden, R. Maple, T. Mulvey, and K. Plaut. 2004. Exogenous TGF-b1 promotes stromal development in the heifer mammary gland. J. Dairy Sci. 87:896-904.

Ormandy, C. J., N. Binart, and P. A. Kelly. 1997. Mammary gland development in prolactin receptor knockout mice. J. Mammary Gland Biol. Neoplasia 2:355-364.

Plath, A., R. Einspanier, C. Gabler, F. Peters, F. Sinowatz, D. Gospodarowicz, and D. Schams. 1998. Expression and localization of members of the fibroblast growth factor family in the bovine mammary gland. J. Dairy Sci. 81:2604-2613.

Plath-Gabler, A., C. Gabler, F. Sinowatz, B. Berisha, and D. Schams. 2001. The expression of the IGF family and GH receptor in the bovine mammary gland. J. Endocrinol. 168:39-48.

Plaut, K. 1993. Role of epidermal growth factor and transforming growth factors in mammary development and lactation. J. Dairy Sci. 76:1526-1538.

Plaut, K., A. J. Dean, T. A. Patnode, and T. M. Casey. 2003. Effect of transforming growth factor-beta (TGF- $\beta$ ) on mammary development. J. Dairy Sci. 86(E. Suppl.):E16-E27.

Plaut, K., and R. L. Maple. 1995. Characterization of binding of transforming growth factor-beta-I to bovine mammary membranes. J. Dairy Sci. 78:1463-1469.

Powers, C. J., S. W. McLeskey, and A. Wellstein. 2000. Fibroblast growth factors, their receptors and signaling. Endocr. Relat. Cancer 7:165-197.

Purup, S., M. Vestergaard, M. S. Weber, K. Plaut, R. M. Akers, and K. Sejrsen. 2000. Local regulation of pubertal mammary growth in heifers. J. Anim. Sci. 78(Suppl. 3):36-47.

Riddle, O., R. W. Bates, and S. W. Dykshorn. 1933. The preparation, identification and assay of prolactin-A hormone of the anterior pituitary. Am. J. Physiol. 105:191-216.

Romangolo, D., R. M. Akers, J. C. Byatt, E. A. Wong, and J. D. Turner. 1994. IGF-I induced IGFBP-3 potentiates the mitogenic actions of IGF-I in mammary epithelial MD-IGF-I cells. Mol. Cell. Endocrinol. 102:131-139.

Rosen, J. M., S. L. Wyszomierski, and D. Hadsell. 1999. Regulation of milk protein gene expression. Annu. Rev. Nutr. 19:407-436.

Sheffield, L. G. 1998. Hormonal regulation of epidermal growth factor receptor content and signaling in bovine mammary tissue. Endocrinology 139:4568-4575.

Shen, Q., and P. H. Brown. 2003. Novel agents for the prevention of breast cancer: Targeting transcription factors and signal transduction pathways. J. Mammary Gland Biol. Neoplasia 8:45-73

Silva, L. F. P., M. J. VanderHaar, M. S. Weber Nielsen, and G. W. Smith. 2002. Evidence of a local effect of leptin in bovine mammary gland. J. Dairy Sci. 85:3277-3286.

Sinowatz, F., D. Schams, S. Kolle, A. Plath, D. Lincoln, and M. J. Waters. 2000. Cellular localization of GH receptor in the bovine mammary gland during mammogenesis, lactation and involution. J. Endocrinol. 166:503-510.

Smith, K. L., and F. L. Schanbacher. 1973. Hormone induced lactation in the bovine. I. Lactational performance following injections of $17 \beta$-estradiol and progesterone. J. Dairy Sci. 56:738-745.

Smith, J. L., and L. G. Sheffield. 2002. Production and regulation of leptin in bovine mammary epithelial cells. Domest. Anim. Endocrinol. 22:145-154.

Stern, D. F. 2003. ErbBs in mammary development. Exp. Cell Res. 284:89-98

Stricker, P., and R. Grueter. 1928. Action du lobe anterieur de l'hypophyse sur la montée laiteuse. CR Soc. Biol. (Paris) 99:1978-1980.

Tucker, H. A. 1981. Physiological control of mammary growth, lactogenesis, and lactation. J. Dairy Sci. 64:1403-1421.

Tucker, H. A. 2000. Hormones, mammary growth, and lactation: A 41-year perspective. J. Dairy Sci. 83:874-884.

Visvader, J. E., and G. J. Lindeman. 2003. Transcriptional regulators in mammary gland development and cancer. Int. J. Biochem. Cell Biol. 35:1034-1051. 
Yang, J., J. J. Kennelly, and V. E. Barcos. 2000. The activity of transcription factor Stat5 responds to prolactin, growth hormone, and IGF-I in rat and bovine mammary explant culture. J. Anim. Sci. 78:3114-3125.

Yang, J., J. J. Kennelly, and V. E. Barcos. 2000. Physiological levels of Stat5 DNA binding activity and protein in bovine mammary gland. J. Anim. Sci. 78:3126-3134.

Weber, M. S., P. L. Boyle, B. A. Corl, E. A. Wong, F. C. Gwazdauskas, and R. M. Akers. 1998. Expression of ovine insulin-like growth factor-1 (IGF-I) stimulates alveolar bud development in mammary glands of transgenic mice. Endocrine 8:251-259.
Weber, M. S., P. L. Boyle, B. A. Corl, E. A. Wong, F. C. Gwazdauskas, and R. M. Akers. 2001. Mammary synthesis of insulin-like growth factor-I in transgenic mice: milk composition and growth of suckling pups. Transgenics 3:143-152.

Weber, M. S., S. Purup, M. Vestergaard, R. M. Akers, and K. Sejrsen. 2000. Regulation of local synthesis of insulin-like growth factor-I and binding proteins in mammary tissue. J. Dairy Sci. 83:30-37.

Weber, M. S., S. Purup, M. Vestergaard, S. E. Ellis, J. SondergardAndersen, R. M. Akers, and K. Sejrsen. 1999. Contribution of insulin-like growth factor (IGF-)-I and IGF-binding protein-3 to mitogenic activity in bovine mammary extracts and serum. J. Endocrinol. 161:365-373. 